\title{
Optimization of activated sludge storage before RNA isolation
}

\author{
Agnieszka CydziK-KwiatKowska*, Marta Wnuk \\ Department of Environmental Biotechnology, University of Warmia and Mazury in Olsztyn, Olsztyn, Poland \\ ${ }^{*}$ Corresponding author: agnieszka.cydzik@uwm.edu.pl
}

\begin{abstract}
Proper sample storage before RNA isolation is crucial for a reliable assessment of microbial activity in activated sludge. In our studies, different amounts of activated sludge expressed in mg of total suspended solids (TSS) were fixed with a constant volume of RNA later RNA Stabilization Reagent (QIAGEN, Germantown, MD, USA) and stored for 3 or 6 months. The results obtained point out that for the best RNA recovery, $1 \mathrm{mg}$ of activated sludge TSS should be fixed with $33 \mu 1$ of the RNA later. It was also observed that a longer storage period ( 6 vs. 3 months) of the activated sludge in RNA later lowered RNA recovery by, on average, $25 \pm 15 \%$ although bacterial diversity in all samples remained unaltered.
\end{abstract}

Key words: activated sludge, RNAlater, RNA isolation

\section{Introduction}

Molecular techniques are used widely in a number of wastewater treatment plants to optimize their operations or to solve problems related with biomass. An investigation of the activity of microbial communities in the activated sludge arising in wastewater treatment processes requires effective RNA isolation from the biomass. RNA molecules are unstable and it is important to apply methodologies and procedures that protect them from degradation, allowing the true level of population biodiversity in the investigated samples to be revealed (Keith et al., 2005; McIlroy et al., 2009). The optimal solution is immediate RNA isolation after sampling. If activated sludge samples are not analyzed immediately, changes in the environmental factors such as organic carbon concentration may shift bacterial group-specific rRNA levels and skew the results of the molecular analyses.

Freezing of samples by immersing in liquid nitrogen or on dry ice is one of the most common means of stabilizing activated sludge samples intended for RNA analysis. These methods were successfully applied in research by Selvaratman et al. (1997) and Oerther et al. (2001). The major drawbacks of these solutions were: availability of the necessary materials, the expense of cold shipping and the necessity to homogenize the samples rapidly to avoid RNA degradation that occurs during thawing of the previously frozen samples. Another possibility is immersing the activated sludge samples in so- lutions that prevent cellular RNA from degradation. The application of commercially available products for RNA protection in cells, e.g. RNA later RNA Stabilization Reagent (QIAGEN, MD, USA) or RNA later ${ }^{\mathrm{TM}}$ Storage Solution (Sigma-Aldrich, MO, USA) simplifies the laboratory protocols. Obtained results confirm the high efficiency of RNA isolation and the ability to analyze mRNA in fixed samples (Grant et al., 2006; Cydzik-Kwiatkowska et al., 2007).

There are reports on the successful use of RNAlater RNA Stabilization Reagent (QIAGEN, Germantown, MD, USA) for tissue storage (Mutter et al. 2004). In general, the manufacturer suggests to use about 10 volumes of the RNA later reagent per one volume of tissue or $1 \mu \mathrm{l}$ of reagent per $1 \mathrm{mg}$ of tissue (RNA later Handbook 2009). Activated sludge is a heterogonous and complicated structure, made up of not only microorganism cells, but also of extracellular polymers, organic and inorganic particles, as well as water. Therefore, activated sludge processing methods remain non-standardized and it is unclear how to use this reagent to best store the collected samples prior to RNA isolation.

Since the storage of RNA laterreagent samples is relatively expensive, when handling a large number of samples, it is important to use them economically. A question arises as to whether the volume of the reagent should be added per unit volume of total suspended solids (TSS) (centrifuged wet activated sludge) or rather 
per a milligram of TSS. Rough estimations showed that after centrifugation, the volume of $3.3 \mathrm{mg}$ of TSS was about $50 \mu \mathrm{l}$. Assuming that the volume of the reagent is 10-times higher than the volume of the sample, it should be fixed with $500 \mu \mathrm{l}$ of RNA later reagent. Calculation of the volume of RNAlater per mg of TSS gives $33 \mu \mathrm{l}$ of the reagent added per $50 \mu \mathrm{l}$ of the centrifuged sample and that amount of the reagent would hardly allow experimenters to suspend the biomass. The calculated volumes differ significantly.

In this work we investigated the suitability of RNA later application for stabilizing RNA in activated sludge. In addition, we determined the influence of the amount of activated sludge stabilized with RNA later on RNA recovery after 3 or 6 months storage of the samples.

\section{Methods}

In our experiments, we used activated sludge with $4 \mathrm{~g} / \mathrm{l}$ TSS concentration (volatile suspended solids VSS, comprised $70 \%$ of TSS) taken from a laboratory tank. TSS and VSS were determined according to APHA (1992). The procedure began with the optimization of the wet weight of centrifuged activated sludge obtained for RNA isolation. The samples were centrifuged at 16,110 $\times g$ for 5 minutes. RNA was isolated in random order using a Total RNA kit (A\&A Biotechnology, Gdynia, Poland) according to the manufacturer's protocol. On the basis of the optimization of results in further experiment, $23 \mathrm{mg}$ of wet weight of the centrifuged activated sludge was used for isolation. In our next experiment, different amounts of activated sludge, namely 2.5, 5, 10 and $15 \mathrm{mg}$ of TSS, were fixed with a constant volume $(500 \mu \mathrm{l})$ of RNA latersolution. Each amount was fixed in duplicate, kept at $4^{\circ} \mathrm{C}$ for $12 \mathrm{~h}$ (Oerther et al., 2001) and then transferred to a refrigerator at $-20^{\circ} \mathrm{C}$. After 3 and then 6 months, RNA was isolated in from each sample. The absorption of UV light by extracts was measured using a BioPhotometer (Eppendorf, Hamburg, Germany). Before the measurement, the RNA isolate was diluted 3 times. The $\mathrm{OD}_{260 / 280}$ ratio was used to evaluate the purity of the isolated RNA samples. The bacterial diversity of the stabilized samples after 6-month storage was assessed using a reverse-transcription PCR (RT-PCR) and denaturing gradient gel electrophoresis (DGGE). The reverse transcription of RNA was conducted as des- cribed earlier (Cydzik-Kwiatkowska et al., 2007). Then the fragments of bacterial $16 \mathrm{~S}$ rRNAs were amplified by PCR involving primers 357F/517R targeting the V3 region (Muzer et al., 2004). PCR reaction mixtures contained $5 \mu \mathrm{l}$ of synthesized first strand cDNA, $0.65 \mathrm{pmol}$ of each primer, $\mathrm{MgCl}_{2}$ in concentration of $1.66 \mathrm{mM}$, each dNTP in concentration of $0.33 \mathrm{mM}$ (Promega, Madison, WI, USA), 1.5 U of GoTaq ${ }^{\circledR}$ DNA Polymerase (Promega, Madison, WI, USA), $3 \mu$ l of buffer supplied with the DNA polymerase and distilled water to a final volume of $30 \mu \mathrm{l}$. It was assumed that the bacterial diversity of activated sludge corresponds to the number of RT-PCR products identified by DGGE. To exclude genomic DNA contamination, the isolated RNA samples were also subjected to PCR. All PCR reactions were performed in an Eppendorf $^{\circledR}$ Mastercycler Gradient (Eppendorf, Hamburg, Germany) using the following program: $95^{\circ} \mathrm{C}$ for $5 \mathrm{~min}$, 35 cycles of denaturation at $94^{\circ} \mathrm{C}$ for $30 \mathrm{~s}$, annealing at $63^{\circ} \mathrm{C}$ for $45 \mathrm{~s}$, extension at $72^{\circ} \mathrm{C}$ for $1 \mathrm{~min}$, and a final elongation at $72^{\circ} \mathrm{C}$ for $5 \mathrm{~min}$. DGGE electrophoresis, the gel staining and visualization were performed as described elsewhere (Cydzik-Kwiatkowska et al., 2010). The DGGE patterns obtained for samples differing in the amount of fixed activated sludge after 6-months of storage were compared with the DGGE pattern obtained from the fresh sample processed as described above on the day of sample fixation. The relationships between the mass of the activated sludge fixed with RNAlater and RNA recovery were determined by correlation analyses using the STATISTICA 8.0 programme (StatSoft, Tulsa, OK, USA). Strength of the correlation was evaluated according to Stanisz (Stanisz, 2000). Statistical difference between the RNA recovery from a given sample after 3 and 6 months storage was analyzed using the two-sided paired Student's $t$-test at the probability level of $95 \%$. In the text, the standard deviation is given after the " \pm ".

\section{Results and discussion}

Prokaryotic RNA can be preserved by various fixation and storage treatments for molecular analyses. Keith et al. (2005) quantitatively analyzed the changes in bacterial group-specific rRNA levels in activated sludge as a function of sample handling and storage procedure. The authors tested four different pre-storage methods. Samples were maintained at room temperature, at $4{ }^{\circ} \mathrm{C}$, treated with phenol and maintained at $4{ }^{\circ} \mathrm{C}$, 
Table 1. Recovery and purity of RNA isolated from activated sludge samples after 3- or 6-months of storage in RNA later. Standard deviation is given after " $\pm ”$

\begin{tabular}{|c|c|c|c|c|c|}
\hline $\begin{array}{c}\text { The efficiency } \\
\text { of RNA isolation } \\
\text { from fresh activated } \\
\text { sludge }[\mathrm{ng} / \mu \mathrm{l}]\end{array}$ & $\begin{array}{l}\text { Time } \\
\text { of storage }\end{array}$ & $\begin{array}{c}\text { The amount of fixed } \\
\text { activated sludge } \\
\text { [mg TSS/500 } \mu \text { l RNA later }]\end{array}$ & $\begin{array}{l}\text { The wet weight of fixed } \\
\text { activated sludge taken } \\
\text { for RNA isolation [mg] }\end{array}$ & $\begin{array}{l}\text { RNA concentration } \\
\text { in isolates }[\mathrm{ng} / \mu \mathrm{l}]\end{array}$ & $\mathrm{OD}_{260 / 280}$ \\
\hline \multirow{8}{*}{$367.3 \pm 10.8$} & \multirow{4}{*}{3 months } & 2.5 & $22.8 \pm 1.0$ & $322.8 \pm 10.0$ & $2.03 \pm 0.02$ \\
\hline & & 5 & $23.7 \pm 0.5$ & $317.3 \pm 9.8$ & $2.04 \pm 0.05$ \\
\hline & & 10 & $22.4 \pm 2.0$ & $374.3 \pm 14.8$ & $2.05 \pm 0.03$ \\
\hline & & 15 & $23.9 \pm 0.3$ & $444.9 \pm 7.7$ & $2.03 \pm 0.04$ \\
\hline & \multirow{4}{*}{6 months } & 2.5 & $22.6 \pm 0.9$ & $196.0 \pm 11.5$ & $2.02 \pm 0.02$ \\
\hline & & 5 & $23.1 \pm 1.1$ & $218.8 \pm 11.3$ & $2.00 \pm 0.03$ \\
\hline & & 10 & $24.0 \pm 1.0$ & $350.1 \pm 9.8$ & $2.06 \pm 0.02$ \\
\hline & & 15 & $23.1 \pm 0.6$ & $355.2 \pm 10.1$ & $2.07 \pm 0.01$ \\
\hline
\end{tabular}
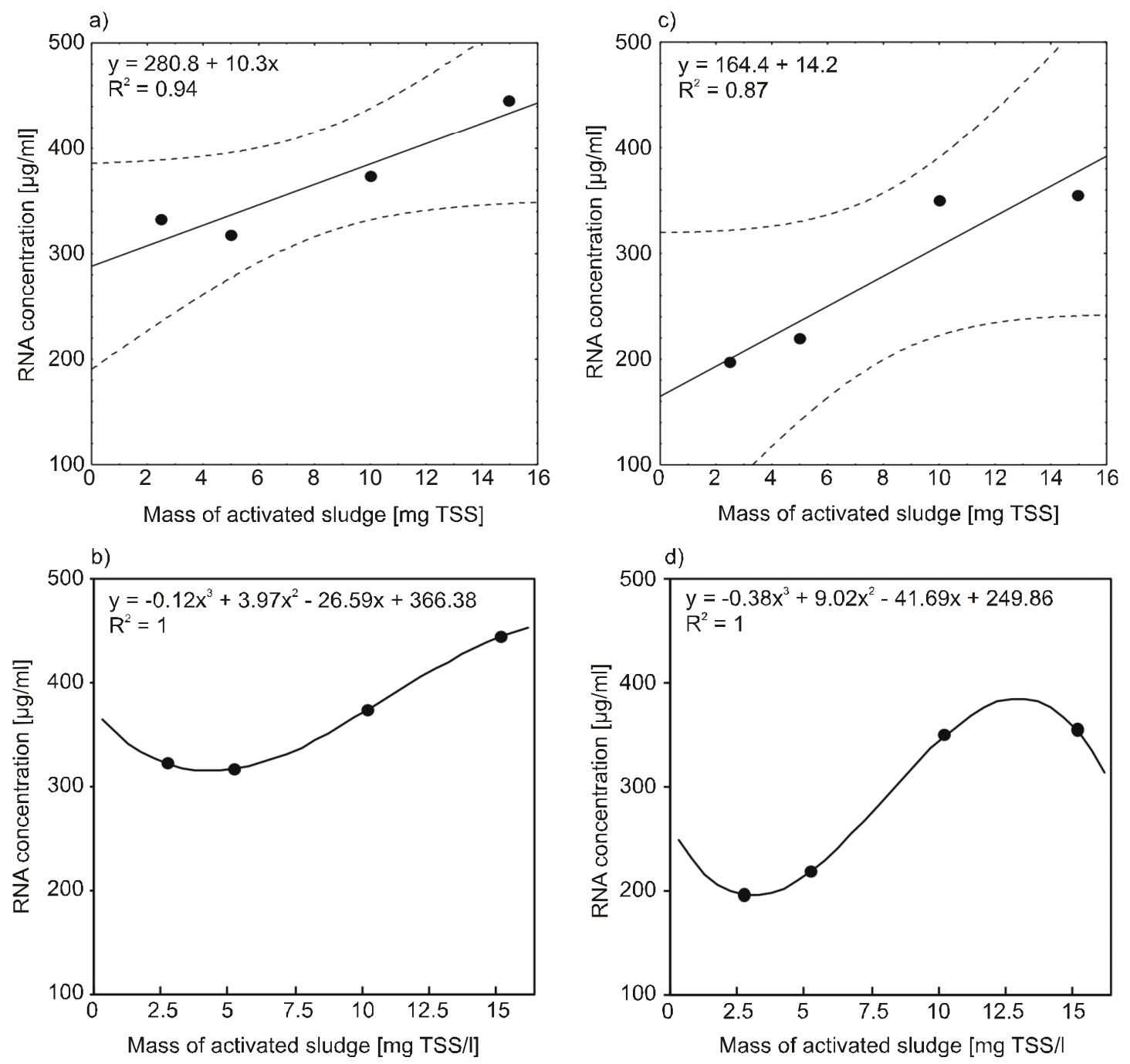

Fig. 1. Efficiency of RNA isolation. Results are presented as points on dispersion graphs (with straight lines representing linear regression equations and curves representing confidence intervals) and as polynomial of degree 3 (with equations). RNA isolation from the fixed samples stored for 3 months graphs a) and b), RNA isolation from the fixed samples stored for 6 months graphs c) and d); each point is the mean of 2 spectrophotometric measurements 
treated with chloramphenicol and maintained at $4{ }^{\circ} \mathrm{C}$. In all cases, samples were kept at the given conditions for $0 \mathrm{~h}, 24 \mathrm{~h}, 48 \mathrm{~h}$ and $72 \mathrm{~h}$ before being frozen. The research proved that the storage of activated sludge at room temperature is a viable option if the freezing or the analysis of samples can be performed within 24 hours, while the treatment with chloramphenicol can extend that time up to $48 \mathrm{~h}$. The lack of treatment, however, did not influence the microbial diversity over time for all the samples.

Bachoon et al. (2001) investigated the effectiveness of maintaining RNA, in Synechococcus and Pseudomonas cells, fixed in $96 \%$ ethanol, $4 \%$ paraformaldehyde, or suspended in RNAlater and held in cold storage for 3 months. Fluorometric analysis of RNA extracted from bacterial cells indicated that the applied storage conditions were equally effective. They did not detect any decrease in the quantity of isolated RNA. The authors also showed that RNA later additionally allowed efficient preservation of RNA in unfrozen samples.

In our experiments, activated sludge was fixed in RNA later in duplicate. In each set of the samples, the mass of activated sludge obtained for fixation was in the range from 2.5 to $15 \mathrm{mg}$ of TSS. The highest amount of TSS used was $15 \mathrm{mg}$, because after suspending in RNA later, the mixture was dense and it would have been difficult to add further biomass. RNA was isolated from ca. $23 \mathrm{mg}$ of the centrifuged activated sludge after 3 and 6 months. Based on OD 260 to 280 ratio, we conclude that all RNA extracts were free of high-level contamination (i.e. with proteins) - Table 1. After both, 3 and 6-month storage of activated sludge in RNA later, the highest RNA concentration (at the constant amount of centrifuged sample taken for isolation) was obtained in samples with the highest amount of activated sludge subjected to fixation. In the sample with $15 \mathrm{mg}$ of TSS and stored for 3 months, the RNA concentration was $444.9 \pm 7.7 \mathrm{ng} / \mu \mathrm{l}$, while when stored for 6 months, it was $355.2 \pm 10.1 \mathrm{ng} / \mu \mathrm{l}$. There was a strong positive correlation, both for 3- and 6-month storage, between the amount of fixed biomass and the RNA concentration in isolates (Fig. 1). The determination coefficient $\left(R^{2}\right)$ was 0.94 and 0.87 for 3- and 6-month storage, respectively. As the composition of RNA later is unknown (patented), it is hard to explain why the reagent preserves RNA better in samples with the higher amount of activated sludge per the unit of the reagent. Literature data (Allewell and Sama, 1974) suggest that various aqueous sulfate salt solutions (e.g. ammonium sulfate) precipitate RNases and other proteins thus preserving the samples with intact RNA. RNA later is probably a commercial preparation of this type of preservatives.

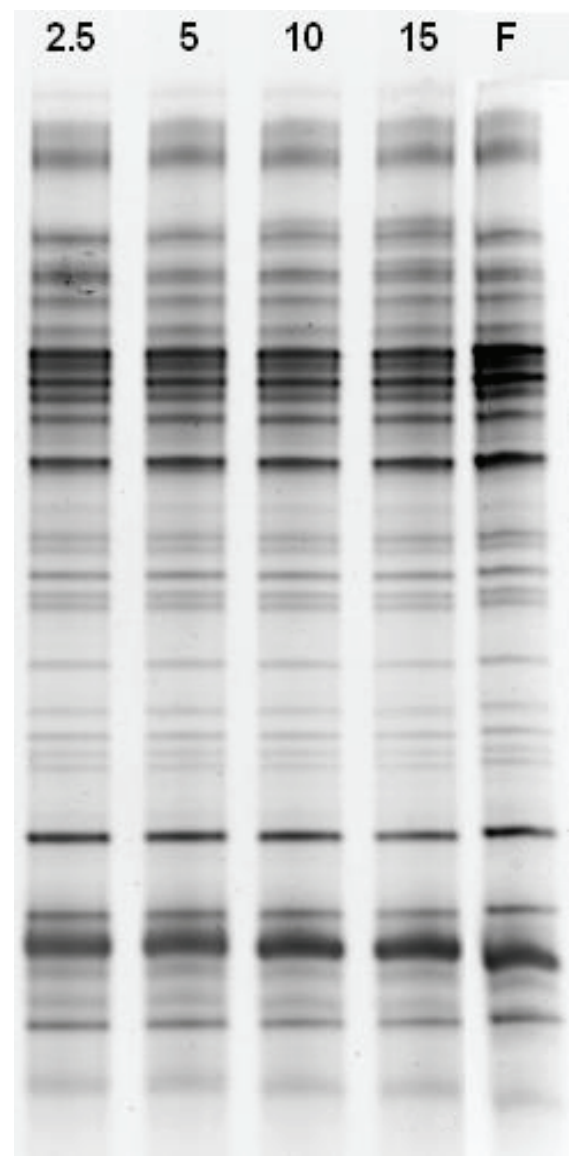

Fig. 2. DGGE of RT-PCR products obtained from the freshly activated sludge and the same activated sludge stored in RNA later for 6 months; lanes are labelled with the numbers representing the amount of activated sludge (expressed in $\mathrm{mg}$ of TSS) fixed with a constant volume of RNA later, the letter F represents the fresh activated sludge sample

There was a statistically significant difference (twosided paired Student's $t$-test; $t=3.9, p \leq 0.03$ ) between the amount of RNA isolated from a given sample after the two periods of time investigated. The recovery of RNA was on average $25 \pm 15 \%$ lower in samples processed after 6 months than it was in the samples stored for only 3 months. To analyze the impact of the storage time of fixed preparations on their bacterial content, we performed RT-PCR reactions on RNA samples. The resulting products were separated by DGGE (Fig. 2). Comparison of the band patterns obtained for the fresh acti- 
vated sludge sample $(\mathrm{F})$ with those obtained for samples differing in the amount of activated sludge fixed in RNA later and stored for 6 months revealed that the bacterial diversity of fixed samples was maintained during the storage. This fact confirms the usefulness of the RNA later reagent for the stabilization of RNA in activated sludge.

The obtained results yield practical information for researchers investigating microorganism activity in activated sludge. The optimal amount of activated sludge fixed with RNA later ensuring good RNA recovery as well as lack of diversity changes and cost savings during the storage, is $1 \mathrm{mg}$ of TSS ( $0.7 \mathrm{mg}$ VSS) per $33 \mu \mathrm{l}$ of the solution. A longer storage period of activated sludge in RNA later influences the amount of RNA in samples. However, the bacterial diversity of samples is preserved.

\section{Acknowledgements}

This work was funded by the research project 528-0809-0801 of the Polish Ministry of Science and Higher Education.

\section{References}

Allewell N.M., Sama A. (1974) The effect of ammonium sulfate on the activity of ribonuclease A. Biochem. Biophys. Acta 341: 484-488.

APHA Standard Methods for the Examination of Water and Waste-water. American Public Health Association, Washington: 1992.

Bachoon D.S., Chen F., Hodson R.E. (2001) RNA recovery and detection of MRNA by RT-PCR from preserved prokaryotic samples. FEMS Microbiol. Lett. 201: 127-132.

Cydzik-Kwiatkowska A., Ciesielski S., Wojnowska-Baryła I. (2007) Bacterial amoA and 16S rRNA genes expression in activated sludge during aeration phase in sequencing batch reactor. Pol. J. Nat. Sci. 22(2): 246-255.
Cydzik-Kwiatkowska A., Zielińska M., Wojnowska-Baryła I. (2010) Impact of operational parameters on bacterial community in a full-scale municipal wastewater treatment plant. Pol. J. Microbiol. (in print).

Grant S., Grant W.D., Cowan D.A., Jones B.E., Ma Y., Ventosa A., Heaphy S. (2006) Identification of eucaryotic open reading frames in metagenomic cDNA libraries made from environmental samples. Appl. Environ. Microbiol. 72(1): 135-143.

Keith J.E., Boyer J.G., de los Reyes III F.L. (2005) Changes in the rRNA levels of specific microbial groups in activated sludge during sample handling and storage. Lett. Appl. Microbiol. 41: 208-215.

McIlroy S.J., Porter K., Seviou R.J., Tillett D. (2009) Extracting nucleic acids from activated sludge which reflects community population diversity. Anton Leeuw 96: 593605.

Mutter G.L., Zahrieh D., Liu C., Neuberg D., Finkelstein D., Baker H.E., Warrington J.A. (2004) Comparison of frozen and RNALater solid tissue storage methods for use in RNA expression microarrays. BMC Genomics 5: 88-95.

Muyzer G., Waal E.C., Uitterlinden A.G. (1993) Profiling of complex microbial populations by denaturing gradient gel electrophoresis analysis of polymerase chain reactionamplified genes encoding for $16 S$ rRNA. Appl. Environ. Microbiol. 59: 695-700.

Oerther D.B., de los Reyes III F.L., de los Reyes M.F., Raskin L. (2001) Quantifying filamentous microorganisms in activated sludge before, during, and after an incident of foaming by oligonucleotide probe hybridizations and antibody staining. Water Res. 35(14): 3325-3336.

RNAlater Handbook. 2009. http://www.qiagen.com/products/ rnastabilizationpurification/rnalaterrnaprotectsystems/ rnalaternastabilization.aspx, accessed 22 August 2010.

Selvaratnam S., Schoedel A., McFarland B.L., Kulpa C.F. (1997)Application of the polymerase chain reaction (PCR) and reverse transcriptase/PCR for determining the fate of phenol-degrading Pseudomonas putida ATCC 11172 in a bioaugmented sequencing batch reactor. Appl. Microbiol. Biotechnol. 47: 236-240.

Stanisz A. (2000) Analiza korelacji. Med. Prakt. 10: 176-181. 